\title{
APLIKASI PUPUK ORGANIK CAIR Gracilaria gigas, CANGKANG TELUR DAN KULIT PISANG TERHADAP PERTUMBUHAN DAN PRODUKSI SAWI CAISIM (Brassica juncea L.)
}

\author{
Vivin Andriani \\ Program Studi Biologi, Fakultas Matematika \& Ilmu Pengetahuan Alam, \\ Universitas PGRI Adi Buana Surabaya \\ Jl. Ngagel Dadi III No.3B/37, Surabaya, Jawa Timur. 60234 \\ E-mail: v.andriani@unipasby.ac.id
}

\begin{abstract}
The aim of this study was to determine the effect of Gracilaria gigas raw liquid organic fertilizer, eggshell and banana peel on the growth and production of cabbage caisim plants and to find out the most optimal concentration on the growth and production of mustard greens. Liquid organic fertilizer made with the composition of Gracilaria gigas $2.5 \mathrm{~kg}$, eggshell $1 \mathrm{~kg}$, banana peel $2.5 \mathrm{~kg}$, water 8 liters, sugar $2 \mathrm{~kg}$, and EM4 1 liter. This study used four treatments with a concentration of each treatment that is $0 \%$ as control, $5 \%, 10 \%, 15 \%, 20 \%$, for 30 days after the cabbage plant is treated. The design used in this study was a Completely Randomized Design consisting of four treatments with six replications. The results showed that administration of liquid organic fertilizer from Gracilaria gigas, eggshells and banana peels had a significant effect $(p<0.05)$ on plant height, number of leaves, and wet weight of mustard greens. The conclusion generated in this study is the use of liquid organic fertilizer from Gracilaria gigas, eggshells and banana peel with a concentration of $10 \%$ can increase the growth and production of cabbage caisim plants well.
\end{abstract}

Keywords: banana peels, cabbage caisim plants, crop production, eggshells, Gracillaria gigas

\section{PENDAHULUAN}

$\mathrm{U}$

nsur hara merupakan salah satu faktor penunjang pertumbuhan dan perkembangan tanaman. Salah satu cara untuk meningkatkan unsur hara adalah penggunaan pupuk. Pupuk yang digunakan untuk meningkatkan unsur hara adalah pupuk kimia karena memberikan dampak yang baik untuk pertumbuhan dan perkembangan tanaman.

Usaha yang dilakukan dalam bidang pertanian untuk mengatasi penggunaan pupuk kimia adalah dengan meningkatkan penggunaan bahan organik. Penggunaan pupuk organik salah satunya dengan bahan baku limbah cangkang telur dan kulit pisang. Menurut Sinaga (2010), cangkang telur dan kulit pisang dimanfaatkan sebagai pupuk organik cair karena mengandung unsur hara yang dibutuhkan tanaman seperti nitrogen, kalium dan fosfor.

Susetya (2012) memaparkan kulit pisang mengandung protein, kalium, magnesium, sodium, sulfur dan fosfor sebesar $63 \mathrm{mg} / 100$ gram. Banyaknya unsur yang terkandung dapat membuat kulit pisang berpotensi dimanfaatkan sebagai pupuk organik. 
Kulit telur juga termasuk sampah organik yang belum dikelola dengan baik. Kandungan kulit telur terdiri dari kalium sebesar 0,121\%; kalsium sebesar 8,977\%; fosfor sebesar 0,394\% dan magnesium sebesar 10,541\%. Kandungan kalsium pada kulit telur yang cukup besar inilah yang dimanfaatkan sebagai pupuk organik bagi tanaman (Aditya, 2014).

Selain fosfor dan kalium, unsur nitrogen juga merupakan unsur hara esensial yang menjadi pembatas dalam pertumbuhan tanaman, $\mathrm{N}$ sangat diperlukan untuk pembentukan atau pertumbuhan bagian-bagian vegetative tanaman seperti daun, batang dan akar. Untuk mendapatkan pupuk cair dengan kandungan N, P, dan K yang tinggi selain dari cangkang telur dan kulit pisang juga ditambahkan makroalga seperti Gracilaria gigas. Penggabungan dari ketiga bahan baku tersebut dapat menambah kandungan unsur hara $\mathrm{N}, \mathrm{P}$ dan $\mathrm{K}$ yang tinggi pada pupuk cair dalam pertumbuhan tanaman.

Jenis alga yang dapat dimanfaatkan sebagai pupuk yaitu Gracilaria gigas. Kemampuan menyerap dan menyimpan air pada Gracilaria inilah yang menjadikan Gracilaria sangat berpotesial digunakan dalam bidamg pertanian (Izzati et al., 2008). Kombinasi bahan kulit pisang, kulit telur dan G. gigas diharapkan menghasilkan pupuk organik cair dengan kandungan $\mathrm{N}, \mathrm{P}, \mathrm{K}$ yang tinggi sebagai unsur esensial yang dibutuhkan dalam pertumbuhan tanaman.

Untuk mengetahui konsentrasi POC berbahan baku Gracilaria gigas, cangkang telur dan kulit pisang yang paling optimal dilakukan pengujian terhadap pertumbuhan tanaman. Dalam penelitian ini pengujian konsentrasi POC yang paling optimal dilakukan pada tanaman sawi caisim (Brassica juncea L.).

Sawi caisim merupakan salah satu jenis sayuran yang sangat disukai oleh masyarakat, kebutuhan akan sayuran sawi caisim ini semakin lama semakin meningkat seiring dengan penambahan populasi manusia serta banyak memberikan manfaat bagi kesehatan. Saat ini, banyak orang yang mengkonsumsi sayuran ini karena manfaatnya bagi kesehatan yaitu untuk mencegah osteoporosis, anemia, kolestrol dan penyakit jantung (Saparinto, 2012). Tanaman sawi caisim ini memiliki banyak kandungan zat gizi yang dibutuhkan oleh tubuh manusia seperti protein, lemak, karbohidrat, $\mathrm{Ca}, \mathrm{P}, \mathrm{Fe}$, vitamin A, vitamin B dan vitamin C (Sunarjono, 2004).

Berdasarkan uraian diatas, penelitian ini bertujuan untuk untuk mengetahui pengaruh pemberian pupuk organik cair berbahan baku Gracilaria gigas, cangkang telur dan kulit pisang terhadap pertumbuhan dan produksi tanaman sawi caisim serta mengetahui konsentrasi yang paling optimal terhadap pertumbuhan dan produksi tanaman sawi caisim. (Brassica juncea L.).

\section{METODE PENELITIAN}

Penelitian ini dilaksanakan selama 3 bulan yakni bulan Januari 2019 sampai Maret 2020. Penelitian dilaksanakan di UPT Proteksi Tanaman Pangan dan Holtikultura Provinsi Jawa Timur, Jl. Pagesangan II No.58 Surabaya.

Bahan yang digunakan dalam penelitian ini terdiri dari 2 bagian yaitu: (1) Bahanbahan yang akan diperlukan dalam pembuatan pupuk ini diantaranya Gracilaria gigas 2,5 kg, cangkang telur $1 \mathrm{~kg}$, kulit pisang 2,5 kg, air 8 liter, gula $2 \mathrm{~kg}$, EM4 1 liter, serta media tanam (tanah 0,5 kg per polybag) dan pupuk dasar 0,5 kg. (2) Bahan-bahan yang akan diperlukan untuk menanam sawi caisim antara lain: biji tanaman sawi caisim (Brassica juncea L.), tanah dan pupuk dasar. 
Alat yang digunakan dalam penelitian ini terdiri dari 2 bagian yaitu: (1) Alat-alat yang diperlukan dalam pembuatan pupuk ini antara lain: ember, botol bekas, gerigen besar 30 liter, saringan, blender, serta pH meter. (2) Alat-alat yang akan diperlukan untuk penyemaian, penanaman dan pengamatan sawi caisim antara lain: timbangan digital, sekrup kecil, gelas ukur, nampan, pisau, sendok, kertas label, gunting, tali, meteran kain, cangkul, polybag $25 \times 25$, buku catatan dan alat tulis, kamera serta hand sprayer ukuran 1 liter.

Jenis penelitian yang digunakan dalam penelitian ini adalah kuantitatif. Penelitian ini menggunakan Rancangan Acak Lengkap (RAL), dengan 4 perlakuan dan 6 ulangan $(\mathrm{PO}=$ konsentrasi $0 \%$ (kontrol), $\mathrm{P} 1=$ konsentrasi $5 \%$ kombinasi pupuk organik cair berbahan baku Gracilaria gigas, cangkang telur dan kulit pisang, P2 = konsentrasi $10 \%$ kombinasi pupuk organik cair berbahan baku Gracilaria gigas, cangkang telur dan kulit pisang dan $\mathrm{P} 3=$ konsentrasi $15 \%$ kombinasi pupuk organik cair berbahan baku Gracilaria gigas, cangkang telur dan kulit pisang.

Prosedur penelitian yang dilakukan meliputi:

\section{Pembuatan POC}

Pada pembuatan pupuk organik cair hal pertama yang harus dilakukan adalah mempersiapkan alat dan bahan Gracilaria gigas 2,5 kg, cangkang telur $1 \mathrm{~kg}$, dan kulit pisang 2,5 kg. Gracilaria gigas dicuci terlebih dahulu dengan air mengalir dengan tujuan menghilangkan kotoran dari tanah serta organisme yang menempel, hal ini dilakukan juga pada cangkang telur dan kulit pisang. Setelah itu mencampur dan memasukkan semua bahan ke dalam blender dengan sedikit diaduk agar bahan tercampur dengan rata, setelah itu tambahkan air 8 liter, gula $2 \mathrm{~kg}$ dan EM4 1 liter, semua bahan tersebut ditimbang untuk mengetahui berat awal, kemudian dimasukkan ke dalam jerigen 30 liter dan dibiarkan selama empat minggu (30 hari).

2. Penyemaian dan penanaman benih sawi caisim (Brassica juncea L.)

Sebelum disemai, benih harus diseleksi terlebih dahulu. Setelah benih siap maka dapat dilakukan pengolahan lahan persemaian dengan menyiapkan nampan plastik dan diisi dengan tanah yang dicampur dengan pupuk dasar dengan perbandingan 2:1. Diamkan lahan persemaian selama dua hari setelah itu taburkan benih sawi caisim yang layak ditanam dan tutup dengan tanah tipis-tipis. Persemaian disiram secara rutin setiap hari yaitu pada sore hari dengan menggunakan sprayer 1 liter. Setelah itu bibit sawi caisim berumur 2 minggu atau sudah memiliki 3-4 helaian daun dipindahkan kedalam polybag.

3. Penyiraman

Penyiraman dengan air sebanyak $300 \mathrm{ml}$ dilakukan setiap hari yaitu pada sore hari, sedangkan penyiraman dengan pupuk organik cair dilakukan setiap 1 minggu sekali yaitu pada sore hari sesuai dengan konsentrasi perlakuan.

4. Pengamatan

Pengamatan dilakukan 4 minggu setelah masa tanam diantaranya mengukur tinggi tanaman sawi caisim menggunakan penggaris dengan cara diukur mulai dari leher akar tanaman sampai ujung daun tertinggi, menghitung jumlah daun dengan cara menghitung daun yang membuka sempurna (daun majemuk). Setelah itu tanaman sawi caisim dicabut dengan hati-hati lalu dibersihkan dari tanah-tanah yang menempel kemudian ditimbang seluruh bagian tanaman meliputi akar, batang dan daun menggunakan timbangan analitik untuk mengetahui berat basahnya 


\section{HASIL PENELITIAN}

\section{A. Tinggi Tanaman}

Hasil penelitian menunjukkan bahwa di antara keempat perlakuan pemberian pupuk organik cair bahan baku Gracilaria gigas, cangkang telur dan kulit pisang memberikan pengaruh yang berbeda. Pada perlakuan $10 \%$ berpengaruh signifikan terhadap tinggi tanaman tanaman sawi caisim (Brassica juncea L.) sebagaimana ditunjukkan pada Gambar 1.

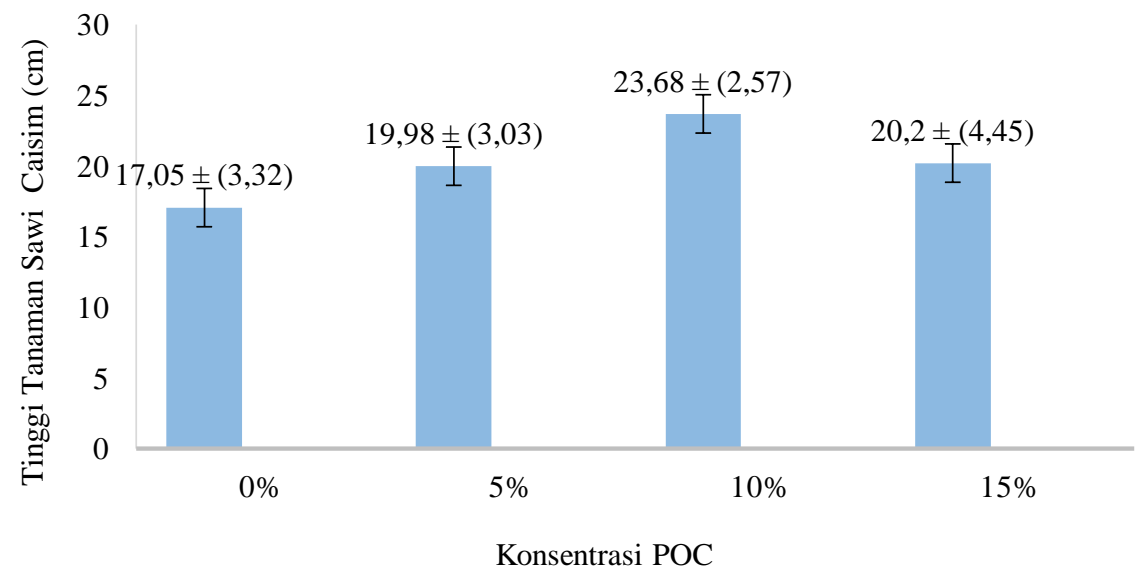

Gambar 1. Rata-rata tinggi tanaman sawi caisim (Brassica juncea L.) setelah diberi perlakuan POC berbahan baku Gracilaria gigas, cangkang telur dan kulit pisang

Berdasarkan hasil uji Duncan Tinggi tanaman sawi caisim dengan pemberian berbagai konsentrasi yaitu Perlakuan 0\% berbeda nyata dengan perlakuan 5\%, 10\% dan $15 \%$ sedangkan antara perlakuan 5\%,10\% dan 15\% tidak berbeda nyata. Perlakuan yang menghasilkan tinggi tanaman terbaik adalah pada perlakuan $10 \%$.

\section{B. Jumlah Daun}

Hasil penelitian menunjukkan bahwa di antara keempat perlakuan pemberian pupuk organik cair bahan baku Gracilaria gigas, cangkang telur dan kulit pisang memberikan pengaruh yang berbeda. Pada perlakuan $10 \%$ berpengaruh signifikan terhadap jumlah daun tanaman sawi caisim (Brassica juncea L.) sebagaimana ditunjukkan pada Gambar 2.

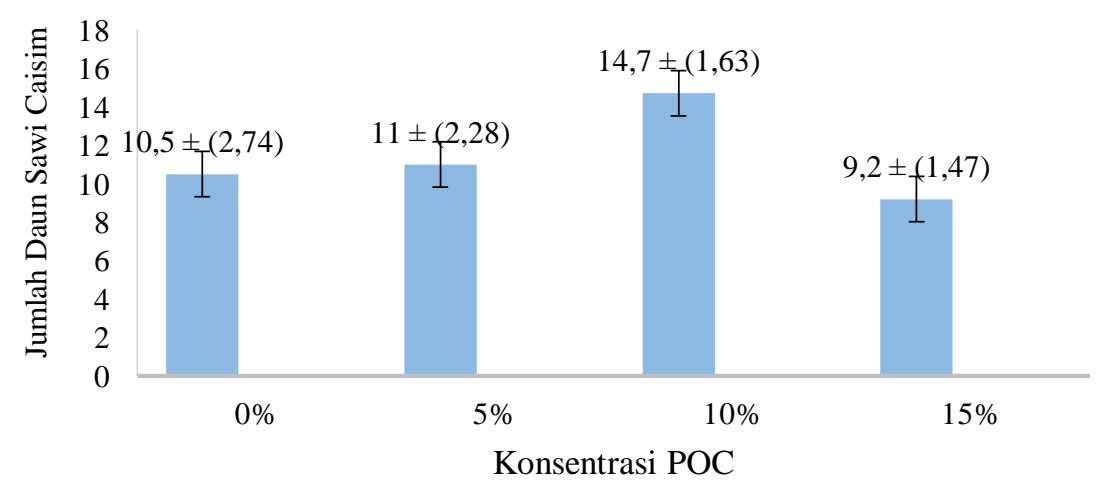


Gambar 2. Rata-rata jumlah daun sawi caisim (Brassica juncea L.) setelah diberi perlakuan POC berbahan baku Gracilaria gigas, cangkang telur dan kulit pisang

Berdasarkan hasil uji Duncan Jumlah daun tanaman sawi caisim dengan pemberian berbagai konsentrasi yaitu Perlakuan $15 \%$ berbeda nyata dengan perlakuan $10 \%$ dan $5 \%$, tetapi tidak berbeda nyata dengan perlakuan $0 \%$. Perlakuan yang menghasilkan jumlah daun tanaman terbaik adalah pada perlakuan $10 \%$

\section{Berat Basah}

Hasil penelitian menunjukkan bahwa di antara keempat perlakuan pemberian pupuk organik cair bahan baku Gracilaria gigas, cangkang telur dan kulit pisang memberikan pengaruh yang berbeda. Pada perlakuan $10 \%$ berpengaruh signifikan terhadap berat basah tanaman sawi caisim (Brassica juncea L.) sebagaimna ditunjukkan pada Gambar 3.

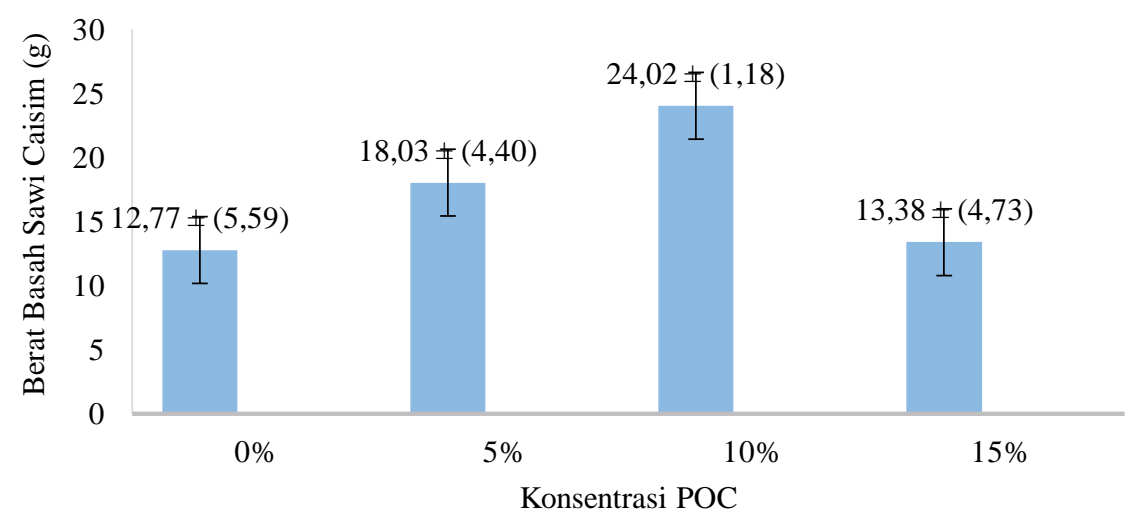

Gambar 3. Rata-rata berat basah sawi caisim (Brassica juncea L.) setelah diberi perlakuan POC berbahan baku Gracilaria gigas, cangkang telur dan kulit pisang

Berdasarkan hasil uji Duncan, jumlah daun tanaman sawi pakcoy yang diamati pada 30 hari setelah tanam dengan pemberian berbagai konsentrasi yaitu perlakuan $10 \%$ berbeda nyata dengan perlakuan $0 \%, 5 \%$ dan $15 \%$. Perlakuan yang menghasilkan berat basah tanaman terbaik adalah pada perlakuan $10 \%$.

Hasil penelitian menunjukkan bahwa terdapat pengaruh pemberian pupuk organik cair berbahan baku Gracilaria gigas, cangkang telur dan kulit pisang terhadap pertumbuhan tanaman sawi caisim dengan parameter tinggi dan jumlah daun, juga dapat berpengaruh terhadap produksi tanaman dengan parameter berat basah tanaman Konsentrasi POC yang paling optimal terhadap pertumbuhan dan produksi tanaman dari penelitian ini yaitu sebesar $10 \%$.

Hal ini disebabkan karena pada konsentrasi $10 \%$ akan menjadi stimulator pada tanaman. Hasil uji kandungan N, P dan K pada pupuk organik cair berbahan baku Gracilaria gigas, cangkang telur dan kulit pisang yaitu $\mathrm{N}=0,11 \%$ sebagai pembentukan atau pertumbuhan bagian-bagian tanaman seperti daun, batang, dan akar, $\mathrm{P}=0,04 \%$ mempercepat pertumbuhan akar dan memperkuat pertumbuhan tanaman muda menjadi tanaman dewasa sedangkan unsur $\mathrm{K}=0,22 \%$ untuk mengeraskan bagian batang tanaman.

Pada data secara statistik diketahui bahwa jumlah daun pada perlakuan konsetrasi $0 \%, 5 \%$ dan $15 \%$ berbeda signifikan dengan perlakuan $10 \%$, namun pada penelitian ini konsentrasi terendah didapat pada perlakuan 15\%. Sedangkan tinggi tanaman terbaik didapat pada perlakuan $10 \%$ dengan rata-rata 14,7. Banyaknya jumlah daun pada 
perlakuan $10 \%$ disebabkan karena unsur hara dalam pupuk organik cair dari bahan baku Gracilaria gigas, cangkang telur dan kulit pisang yang dibutuhkan untuk perbanyakan jumlah daun digunakan dalam takaran yang sesuai dan dapat merangsang pertumbuhan tanaman sawi. Peningkatan perbanyakan jumlah daun disebabkan oleh adanya pembesaran dan pembelahan sel.

Dalam pertumbuhan jumlah daun sangat memerlukan unsur hara seperti nitrogen dan fosfor. Unsur hara yang dibutuhkan ini terdapat pada pupuk organik cair dari bahan baku Gracilaria gigas, cangkang telur dan kulit pisang. Hal ini sesuai dengan pendapat Mufida (2013), bahwa unsur hara nitrogen dapat merangsang pertumbuhan vegetatif (warna hijau) seperti daun yang sangat berguna dalam proses fotosintesis. Dengan penyerapan hara nitrogen akan dapat meningkatkan pembentukan dan pertumbuhan daun pada tanaman. Tersedianya unsur nitrogen dalam jumlah yang cukup bagi tanaman akan memperlancar proses metabolisme tanaman dan mempengaruhi pertumbuhan organorgan seperti daun, batang dan akar pada tanaman.

Pada data secara statistik diketahui bahwa berat basah pada perlakuan konsetrasi $0 \%, 5 \%$ dan $15 \%$ berbeda signifikan dengan perlakuan $10 \%$, namun pada penelitian ini konsentrasi terendah didapat pada perlakuan 0\%. Sedangkan tinggi tanaman terbaik didapat pada perlakuan $10 \%$ dengan rata-rata $24,02 \mathrm{~g}$. Tingginya berat basah pada perlakuan $10 \%$ disebabkan karena terdapat kandungan unsur hara nitrogen pada POC dimana nitrogen sendiri dapat meningkatkan perbandingan protoplasma terhadap dinding sel dan dapat mengakibatkan bertambah besar ukuran sel dengan dinding sel yang tipis, keadaan ini mengakibatkan daun banyak mengandung air. Air merupakan salah satu faktor yang menentukan proses pertumbuhan tanaman. Tanaman membutuhkan air dari tanah serta $\mathrm{CO}_{2}$ dari udara untuk membentuk gula dan karbohidrat dalam proses fotosintesis serta sebagai pelarut unsur hara sehingga unsur hara dapat diserap oleh akar tanaman (Hardjowigeno, 2013).

Berdasarkan pengujian kadar unsur hara pupuk organik cair menunjukkan bahwa unsur hara N, P dan K pada pupuk organik cair dari Gracilaria gigas, cangkang telur dan kulit pisang berturut-turut yaitu unsur hara $\mathrm{N}$ sebesar $0,11 \%$, P sebesar $0,04 \%$, K sebesar $0,22 \%$. Adapun kriteria berdasarkan standar baku mutu hara tanah oleh Hadjowigeno (2003) menunjukkan bahwa kadar $\mathrm{N}$ termasuk kategori tinggi $(>0,10)$; kadar P kategori sangat tinggi $(>0,035)$ dan kadar $\mathrm{K}$ kategori sangat tinggi $(>0,06)$. Berdasarkan kriteria komposisi unsur hara di atas, pupuk organik cair ini dapat digunakan untuk diaplikasikan pada tanaman karena tingginya unsur hara N, P dan $\mathrm{K}$ yang terkandung di dalamnya (Rosmarkam dan Yuwono, 2001).

\section{KESIMPULAN}

Berdasarkan analisis dan pembahasan data hasil penelitian dapat disimpulkan bahwa terdapat pengaruh pemberian pupuk organik cair berbahan baku Gracilaria gigas, cangkang telur dan kulit pisang berpengaruh terhadap pertumbuhan tanaman sawi caisim dengan parameter tinggi dan jumlah daun, juga dapat berpengaruh terhadap produksi tanaman dengan parameter berat basah tanaman. Konsentrasi POC yang paling optimal terhadap pertumbuhan dan produksi tanaman dari penelitian ini yaitu sebesar $10 \%$. 


\section{DAFTAR PUSTAKA}

Aditya, AR. (2014). Peranan Ekstrak Kulit Telur, Daun Gamal dan Bonggol Pisang Sebagai Pupuk Organik terhadap Pertumbuhan Tanaman Cabai dan Populasi Aphis craccivora Pada Fase Vegetatif. Halaman Diakses dari http://repository.unhas.ac.id.

Hardjowigeno, S. (2003). Ilmu Tanah. Jakarta: Akademika Pressindo.

Izzati, M et al. (2008). Kapasitas Penyerapan dan Penyimpanan Air pada Berbagai Ukuran Potongan Rumput Laut Gracilaria verrucosa sebagai Bahan Dasar Pupuk Organik.Halaman diakses dari http://eprints.undip.ac.id/.

Jumroh. (2014). Penggunaan Gracilaria gigas sebagai Bahan Organik pada Media Tanam dalam Meningkatkan Pertumbuhan Tanaman Kedelai Varietas Anjasmoro. Jurnal LenteraBio, 3(3), 248254.

Mufida, L. (2013). Pengaruh Penggunaan Konsentrasi FPE (Fermented Plant Extract) Kulit Pisang terhadap Jumlah Daun, Kadar Klorofil dan Kadar Kalium pada Tanaman Seledri (Apium graveolens) [Skripsi]. Semarang: IKIP PGRI Semarang.

Rosmarkam, A dan Yuwono NW. (2001). Ilmu Kesuburan Tanah. Yogyakarta: Kanisius.

Saparinto, C. (2012). Panduan Praktis Menanam 14 Sayuran Konsumsi Populer di Pekarangan. Yogyakarta: Penerbit ANDI.

Sinaga, D. (2010). Pembuatan Pupuk Cair dari Sampah Organik dengan Menggunakan Boisca sebagai Starter [Skripsi]. Medan: Universitas Sumatera Utara.

Susetya, Darma. (2012). Panduan Lengkap Membuat Pupuk Organik untuk Tanaman Pertanian dan Perkebunan. Yogyakarta: Pustaka Baru Press.

Syam et al. (2014). Pengaruh Cangkang Telur Ayam Ras Terhadap Pertumbuhan Tanaman Kamboja Jepang (Adenium obesum). e-Jipbiol, 3(10): 9-15. 